\title{
Functional characteristics of macroinvertebrate communities in Mediterranean ponds (Central Italy): Influence of water permanence and mesohabitat type
}

\author{
Marcello Bazzanti*, Valentina Della Bella and Francesco Grezzi \\ Department of Animal and Human Biology, “Sapienza” University of Rome, viale dell’Università 32, 00185 Rome, Italy
}

Received 30 September 2008; Accepted 9 January 2009

\begin{abstract}
The macroinvertebrate fauna of twenty-one ponds (thirteen temporary and eight permanent) located in four protected areas in Central Italy were studied in March, May and June 2002, with the aim to bring out relationships between environmental variables and the functional characteristics (functional feeding groups, habits and resistance to drought) of communities. Macroinvertebrates were collected in three mesohabitat types (macrophyte beds, littoral sediments, central sediments). Overall, the functional attributes of temporary and permanent pond communities did not differ greatly. However, at the mesohabitat scale, collector-gatherers, burrowers and permanent residents capable of passive dispersal were more abundant in sediments. Scrapers and shredders, sprawlers and climbers, swimmers and divers, and organisms capable of active dispersal which lack drought resistance were more abundant in macrophyte beds. Although hydroperiod is the main driving factor affecting community structure, our results suggest that it remains an unimportant factor in controlling functional traits, which appeared to be more influenced by substratum types. Moreover, the positive relationship between taxonomic and functional diversity metrics indicates that an increase in taxonomic richness induces a satisfactory partitioning of the ecological resources among taxa, thus maintaining the ecological complexity of the ponds regardless of their hydroperiod length.
\end{abstract}

Key words: Astatic ponds / macroinvertebrates / functional feeding groups / habits / responses to desiccation / taxonomic diversity / functional groups

\section{Introduction}

Ponds usually host high species richness and have been recognised as important reservoirs of threatened and rare species which make an irreplaceable contribution to biodiversity (i.e. Biggs et al., 1994; Collinson et al., 1995; Oertli et al., 2002; E.P.C.N., 2007; Nicolet et al., 2007). Moreover, they constitute field laboratories for testing ecological hypotheses concerning the communities living in them (De Meester et al., 2005). Due to their drastic numerical decrease caused by urban and agricultural practices, ponds are studied for several aspects related to biodiversity patterns as a function of environmental conditions (i.e. Bazzanti et al., 2000, 2003, 2008; Batzer et al., 2004; Studinski and Grubbs, 2007; Della Bella et al., 2005, 2007, 2008), and for the assessment of their conservation value (Collinson et al., 1995; Oertli et al., 2002; Nicolet et al., 2004; Solimini et al., 2008).

\footnotetext{
*Corresponding author: marcello.bazzanti@uniroma1.it
}

Whilst the functional organization of macroinvertebrate communities in running water is well documented (Vannote et al., 1980; Kerans and Karr, 1994; Barbour et al., 1999), few studies have focused on lakes (Dvořak and Best, 1982; Dvořak, 1996) and ponds (Higgins and Merritt, 1999; Heino, 2000; Bazzanti and Della Bella, 2004). As regards the functional traits of pond invertebrates, survival to drought (sensu Wiggins et al., 1980) and habits (defined here as mode of attachment, concealment and locomotion) (Merrit and Cummins, 1996) have been poorly investigated. Analyses on survival to drought have been carried out especially in phenological studies of temporary ponds (Williams, 1985; Lake et al., 1989; Bataille and Baldassarre, 1993; Bazzanti et al., 1996; Culioli et al., 2006), whereas comparisons between ponds with different wet phase length are still scarce (Schneider and Frost, 1996; Gascon et al., 2008). Finally, habits were found to be practically unknown for pond organisms (Bazzanti and Della Bella, 2004). Despite a recent surge of interest in ponds, relatively few theories linking functional aspects of macroinvertebrate communities to 
their environment have actually emerged. In particular, how macroinvertebrates are organized with respect to their feeding modalities, habits and strategies to survive drought is still virtually unknown, while few testable hypotheses regarding their functional relationships with environmental parameters have been generated.

Two previous studies (Della Bella et al., 2005; Solimini et al., 2005) revealed differences in the taxonomic composition and size spectra of macroinvertebrate communities among 13 temporary and 8 permanent Mediterranean ponds located in Central Italy, and among three mesohabitats types (littoral and central sediments, and macrophyte beds). In this paper we studied the same ponds, with the aim to bring out relationships between environmental parameters and functional aspects of the communities related to functional feeding groups (FFGs), habits and survival to drought. In particular, we examined whether communities of permanent and temporary ponds, and from different mesohabitat types, have different FFGs, habits and survival modalities. We discussed the influence of hydroperiod on the functional diversity of communities, and the relationships between functional feeding groups, habits and resistance to drought, and taxonomic diversity in relatively pristine ponds.

\section{Material and methods}

\section{Study area}

Twenty-one ponds (eight permanent and thirteen temporary) were sampled in four protected areas (WWF Oasis of Palo Laziale, Litorale Romano Natural State Reserve, Decima Malafede Natural Reserve, and Presidential Estate of Castelporziano) along the Tyrrhenian coast of Central Italy (Fig. 1). These sites are protected under European directives (79/409/EEC; 92/43/EEC) or as part of the Natura 2000 network (see Regione Lazio, 2004). This area is representative of the last residue of the original Mediterranean plain forest formerly covering the Latium coast, now surrounded by an urban and agricultural landscape. The thirteen temporary ponds are autumnal ponds (sensu Wiggins et al., 1980) and their hydroperiod length depends on the rainfall, which usually shows autumnal and spring peaks. During the study year (2002), one temporary pond held water for 60 days, three had a wet phase duration between 100 and 200 days, and nine between 200 and 300 days. No significant relationship between pond community similarity and their geographic distance was found for both temporary and permanent ponds (Della Bella et al., 2006).

\section{Sampling and laboratory methods}

We sampled macroinvertebrates in March, May and June 2002, covering the period of the year generally characterized by the greatest richness of macroinvertebrate species in Central Italian ponds (Bazzanti et al.,

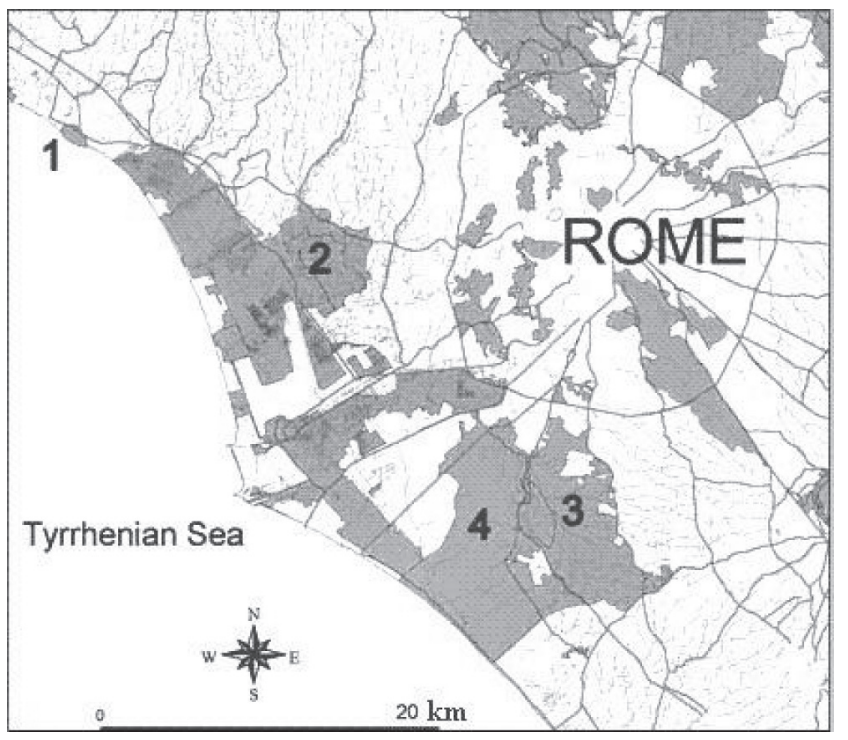

Fig. 1. Map of the sampling site showing the four protected areas: $1=$ WWF Oasis of Palo Laziale; 2 = Litorale Romano Natural State Reserve; 3 = Decima Malafede Natural Reserve; $4=$ Presidential Estate of Castelporziano.

1996). Due to an unusually dry spring, seven temporary ponds dried up at the end of May. We therefore sampled twenty ponds in March and May and thirteen ponds in June.

We used a pond net $(0.280 \mathrm{~mm}$ mesh opening $)$ to trawl for macroinvertebrates in three main contrasting mesohabitats: emergent and submerged aquatic vegetation, unvegetated littoral sediments and unvegetated central sediments. The concept of mesohabitat has been successfully adopted for studying streams (Pardo and Armitage, 1997, Tockner et al., 2000) and, more recently, for lakes (Tolonen et al., 2001; White and Irvine, 2003). Mesohabitats are defined as visually distinct and easily identifiable habitats within the freshwater body. Overall, 123 samples of macroinvertebrates proved suitable for analysis. A more detailed description of the sampling methods can be found in Della Bella et al. (2005), Solimini et al. (2005) and Bazzanti et al. (2008).

The material was preserved in $10 \%$ formalin to which was added Bengal Rose stain to facilitate the sorting of organisms. Individuals were identified to lowest possible taxonomic level and assigned to different FFGs, habits (mode of attachment, concealment and locomotion), and groups of survival strategies following Merritt and Cummins (1996), Cummins and Wilzbach (1985), Wiggins et al. (1980), our own experience and suggestions of taxonomic specialists (Appendix 1 available at www. limnology-journal.org). Further explanations of the Wiggins et al. (1980) groups can be found in Bataille and Baldassarre (1993), Schneider and Frost (1996), Higgins and Merritt (1999) and Gascon et al. (2008). Clingers were not considered because they are typically found in running waters or in rocky littoral zones of lakes (see Merritt and Cummins, 1996). 
Table 1. Environmental characteristics of the twenty-one study ponds. $\mathrm{P}=$ Permanent, $\mathrm{T}=$ Temporary. Mean values from ponds of the same type are reported. Water turbidity is expressed as median value.

\begin{tabular}{|c|c|c|}
\hline \multirow[b]{2}{*}{ Environmental parameters } & \multicolumn{2}{|c|}{ Pond type } \\
\hline & $\mathrm{P}$ & $\mathrm{T}$ \\
\hline Water permanence (days) & 365 & 220.8 \\
\hline Macrophyte cover ( $\%$ of pond area) & 61.9 & 40 \\
\hline Number of macrophyte species & 6.2 & 3.3 \\
\hline Phophorus in the sediments (g.kg ${ }^{-1}$ ) & 0.521 & 0.402 \\
\hline Nitrogen in the sediments $(\%)$ & 0.154 & 0.181 \\
\hline Phosphorus in the water (mg. $\left.\mathrm{L}^{-1}\right)$ & 0.207 & 0.316 \\
\hline Nitrogen in the water (mg.L ${ }^{-1}$ ) & 1.53 & 3.66 \\
\hline Maximum depth $(\mathrm{cm})$ & 77.6 & 24 \\
\hline Surface area $\left(\mathrm{m}^{2}\right)$ & 3550.3 & 143.6 \\
\hline Dissolved oxygen $\left(\mathrm{mg} \mathrm{L}^{-1}\right)$ & 10.9 & 5.6 \\
\hline Organic carbon in the sediment $(\%)$ & 1.16 & 1.53 \\
\hline Organic matter $(\%)$ & 10.9 & 10.5 \\
\hline Conductivity $\left(\mu\right.$ S.cm $\left.{ }^{-1}\right)$ & 884 & 704 \\
\hline $\mathrm{pH}$ & 8.6 & 7.4 \\
\hline Water turbidity* & 1 & 3 \\
\hline Coarse sand (\%) & 3.1 & 2.7 \\
\hline Medium sand $(\%)$ & 14.2 & 15.3 \\
\hline Fine sand $(\%)$ & 11.4 & 15 \\
\hline Silt $(\%)$ & 44.4 & 35 \\
\hline Clay $(\%)$ & 27.4 & 31.8 \\
\hline Tree cover ( $\%$ of pond area) & 8.7 & 12.5 \\
\hline
\end{tabular}

*Class: 1 = clear, 2 = intermediate, 3 = turbid.

At each visit we measured the maximum depth and the area of ponds as reported by Bazzanti et al. (1996). Conductivity, $\mathrm{pH}$, and dissolved oxygen were recorded using electronic meters. We calculated organic matter content and granulometric composition of the sediments, total nitrogen, total phosphorus and organic carbon content, according to Cummins (1962), Gaudette et al. (1974), Marengo and Baudo (1988), and Bremner (1965), respectively. Total nitrogen and phosphorus concentrations in the water were determined following standard methods (IRSA-CNR, 1994; Wetzel and Likens, 2000). Finally, we visually mapped riparian tree and aquatic macrophyte covers and recorded the number of macrophyte species for each pond. Physical and chemical data of the study ponds are reported in Table 1. Permanent ponds showed significantly higher values of surface area and maximum depth, water transparency, conductivity, dissolved oxygen, $\mathrm{pH}$, macrophyte species richness, and lower content of total nitrogen and phosphorus in the water than temporary ponds (Bazzanti et al., 2008; Della Bella et al., 2008).

\section{Statistical analyses}

Non-Metric Multidimensional Scaling (N-MDS) was performed on the similarity matrix based on the BrayCurtis similarity coefficient (Clarke and Warwick, 1994) in order to summarize variations among sites taking the percentages of functional categories into account. Before the analyses, the data referring to the biological variables were $\arcsin \sqrt{ } \mathrm{p}$ transformed in order to stabilize the variance (Sokal and Rohlf, 1973). In order to assess the effects of pond type (permanent vs. temporary) on functional group abundances, the Mann-Whitney nonparametric U test was used. Comparisons were performed separately for each date. Further, to test the distribution of the functional parameters within the ponds we selected the highest number of ponds (ten ponds, including six permanent and four temporary) simultaneously displaying all the three considered mesohabitats on the same sampling occasion (May, 2002). Differences were estimated by two-ways ANOVA and the post-hoc Tukey test (level of $P<0.01$ ) using percentage data previously transformed in arcosin $\sqrt{ } \mathrm{p}$ (Sokal and Rholf, 1973). Finally, in agreement with previous works (Ross et al., 2001; Usseglio-Polatera et al., 2001; Heino, 2005), we adopted the Shannon diversity index (Pielou, 1969) to calculate taxonomic diversity $\left(\mathrm{H}_{\mathrm{tax}}\right)$ and three functional diversity metrics (feeding groups $=\mathrm{H}_{\mathrm{ffg}}$, habits $=\mathrm{H}_{\text {hab }}$, and Wiggins groups $=\mathrm{H}_{\mathrm{wig}}$, and Pearson's $\mathrm{R}^{2}$ was employed to test relations between them. We performed our statistical analyses with Statistica (version 5) and PRIMER 5 (version 5.2.0) softwares.

\section{Results}

\section{Differences between pond typologies}

The FFG analysis revealed the dominance of collectorgatherers and secondarily of predators in both pond typologies and for all three sampling occasions (Fig. 2). Only the percentages of collector-filterers in May (MannWhitney U-test: $P<0.05$ ) and scrapers in March and June (Mann-Whitney U-test: $P<0.01$ ) were found to be higher in perennial biotopes than in temporary ones.

As regards the habit categories, burrowers (inhabiting fine sediments) and sprawlers + climbers (staying or mobile forms on the substrate) and secondarily swimmers + divers (mobile forms in water) dominated in the studied ponds (Fig. 2). No significant differences were noted in pond typologies in any of the habit categories on the three sampling occasions.

Figure 2 also shows that the percentage composition of the four groups defined according to Wiggins et al. (1980) was very similar between temporary and permanent ponds, except for Group 4 components which were more abundant (Mann-Whitney U-test: $P<0.01$ ) in permanent ponds in March. The N-MDS (Fig. 3), performed on percentage data (expressed for ponds) of FFGs, habits and Wiggins groups considered together, confirmed the strong similarity between the two pond typologies that had already emerged from the data for each functional group.

\section{Differences among mesohabitats}

As regards FFGs (Fig. 4) collector-gatherers showed significant differences among the three mesohabitats 

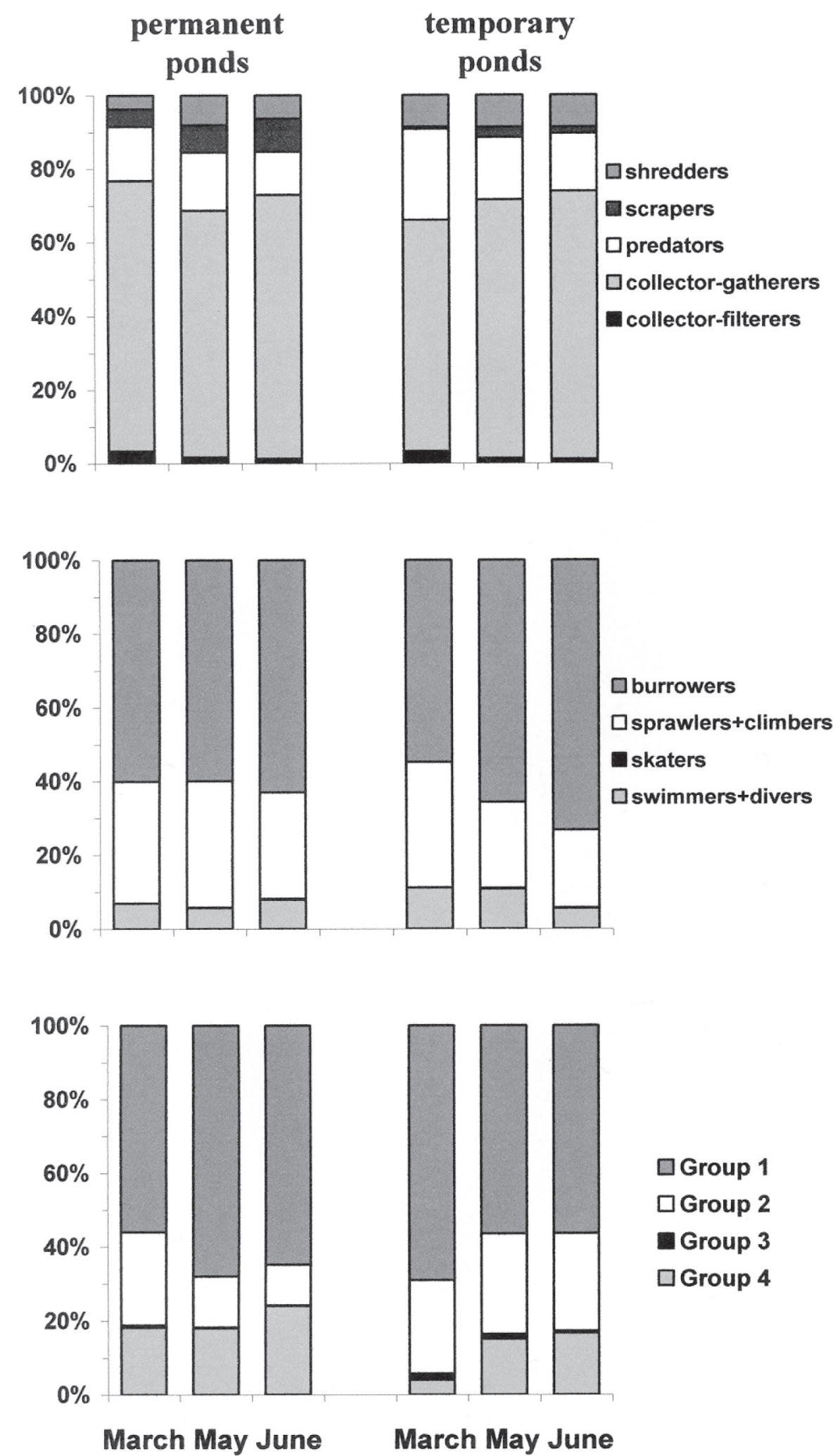

Fig. 2. Mean percentage composition of functional groups (functional feeding groups, habits and Wiggins Groups) in the two pond types during the three study months.

(ANOVA: $\mathrm{F}_{2,16}=18.30, P<0.001$ ), with higher abundances in the littoral and central sediments compared to the macrophyte stands (Tukey test: $P<0.001$, for both sediment types). Scrapers and shredders also showed a different distribution among mesohabitats (ANOVA: $\mathrm{F}_{2,16}=18.30, P<0.001$ and $P<0.01$, respectively), with 


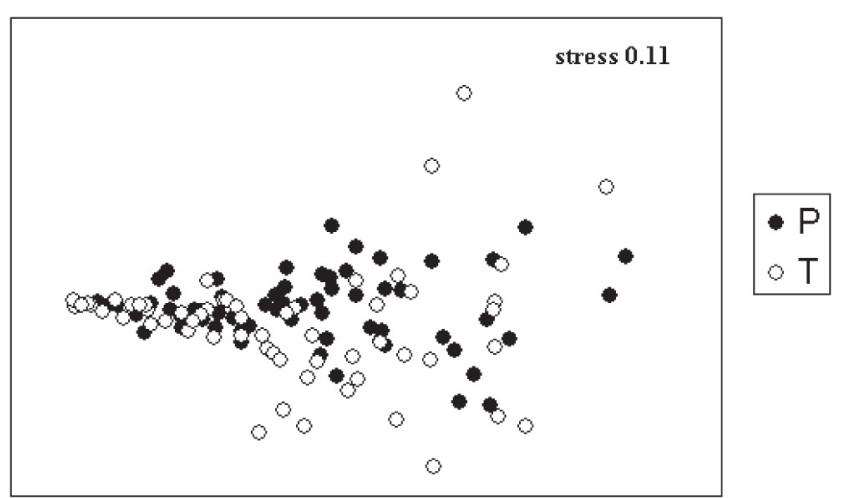

Fig. 3. Plot of Non-Metric Multidimensional Scaling (N-MDS) performed on the abundances of functional groups during the three study months. $\mathrm{P}=$ permanent ponds, $\mathrm{T}=$ temporary ponds.

a greater abundance in the macrophyte beds (Tukey test: $P<0.001$ and $P<0.01$, respectively). Some differences were found for habits (Fig. 4): sprawlers + climbers and swimmers + divers showed higher abundances in the macrophyte beds (ANOVA: $\mathrm{F}_{2,16}=24.35$ and $\mathrm{F}_{2,16}=$ 13.78, respectively, Tukey test: $P<0.001$, for both groups). Burrowers dominated in the littoral and central sediments (ANOVA: $\mathrm{F}_{2,16}=35.29, P<0.001$; Tukey test: $P<0.001$, for both sediment types). Finally, for the adaptive strategies of Wiggins, Group 4 (most Coleoptera, Hemiptera and Diptera) showed a different distribution (ANOVA: $\mathrm{F}_{2,16}=11.30, P<0.001$ ), characterized by dominance in the macrophyte beds compared to the littoral (Tukey test: $P<0.001$ ) and central (Tukey test: $P<0.01$ ) sediments (Fig. 4). Group 1 (Oligochaeta, Nematoda, Turbellaria, Crustacea Anostraca and Notostraca, Mollusca) was more abundant above or inside both sediment types (ANOVA: $\mathrm{F}_{2,16}=11.30, P<0.001$; Tukey test: $P<0.001$ ). The N-MDS (Fig. 5) performed on percentage data (expressed for mesohabitats) of FFGs, habits and Wiggins groups considered together, pointed to a clear separation between macrophyte beds and the two types of sediments, the latter appearing similar to each other.

\section{Taxonomic diversity vs. functional diversity metrics}

Taxonomic diversity $(\mathrm{H})$ was found to be significantly correlated (at least $P<0.05$ ) with functional diversity metrics calculated using feeding groups $\left(\mathrm{H}_{\mathrm{ffg}}\right)$, habits $\left(\mathrm{H}_{\text {hab }}\right)$ and Wiggins groups $\left(\mathrm{H}_{\text {wig }}\right)$ on all three sampling occasions (Fig. 6). No significant differences were recorded in taxonomic diversity, neither in functional diversities between the two types of ponds on any of the sampling occasions (Mann-Whitney U-test: $P>0.05$ ). All diversity metrics proved to be higher in macrophyte beds than in the two other substrates, but only differences in FFGs and habits were significant (ANOVA: $\mathrm{F}_{2,16}=11.63, P<0.001$ and $\mathrm{F}_{2,16}=4.64, \quad P<0.05 ;$ Tukey test $P<0.001$ and $P<0.05$, respectively).

\section{Discussion}

\section{Differences between pond types}

Our analysis of the FFG percentage composition showed the dominance of collector-gatherers and predators in the study ponds (see also Higgins and Merritt, 1999; Bazzanti and Della Bella, 2004). Moreover, in our study only collector-filterers and scrapers were significantly more abundant in permanent than in temporary ponds. So, these two FFGs can be influenced by pond features and water chemistry which directly or indirectly tend to favour (or reduce) algae and/or macrophyte growth and richness. Filter-feeding activity is exploited mostly by bivalves (Musculium lacustre and Pisidium spp.) and by some chironomid taxa (Paratanytarsus sp., Cladotanytarsus mancus group, Dicrotendipes nervosus group and Endochironomus tendens). As observed in previous papers on ponds in Central Italy (Bazzanti et al., 2000, 2003, 2008; Bazzanti and Della Bella, 2004), these organisms seem to prefer permanent waters, where high conductivity and greater depth may contribute advantages regarding feeding - the chemical environment favouring a growth of seston (algae) and the depth/size of the ponds providing more water to be filtered compared to temporary ponds. The higher abundances of scrapers (mostly the gastropod species and the mayfly Cloeon dipterum) in our permanent ponds were dependent on the larger number of species and cover of macrophytes in these ponds than in temporary biotopes (cf. Della Bella et al., 2008). In a previous study on twenty other ponds in the same area (Bazzanti and Della Bella, 2004), we found high abundances of this trophic group in both pond types with high macrophyte cover and species richness. Scrapers, therefore, seem to be independent of hydroperiod length but indirectly affected by water transparency and chemistry which tend to favour the growth and richness of their food, represented by periphytic algae, and living and senescent macrophytes. Finally, the abundances of shredders, predators and collector-gatherers were very similar in the two pond types.

As regards the habit organization in ponds, our communities appeared very similar in temporary and permanent ponds which were both dominated by burrowers and sprawlers + climbers, followed by swimmers + divers (nektonic forms), the latter usually constituting an appreciable proportion of the community (Williams, 1987). These results confirm the findings of our previous paper (Bazzanti and Della Bella, 2004).

As regards the adaptive modality to resist drought, Schneider and Frost (1996) showed that the number of taxa belonging to the different Wiggins et al. (1980) groups were affected by hydroperiod length in temporary vernal ponds in USA, whereas Gascon et al. (2008) reported that the absolute densities of some functional groups were 

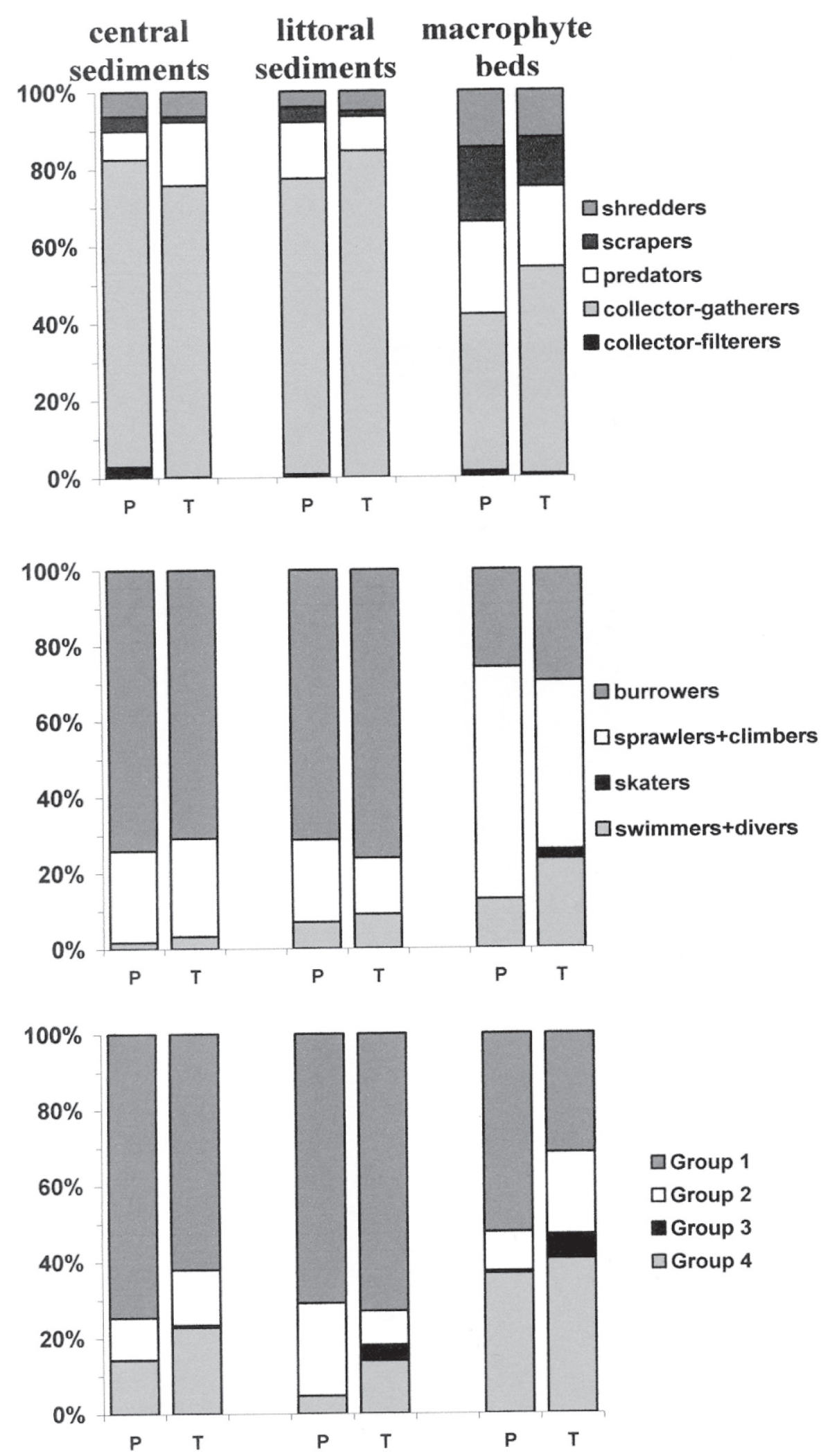

Fig. 4. Mean percentage composition of functional groups (functional feeding groups, habits and Wiggins Groups) in the different mesohabitats of 10 selected ponds in May 2002. $\mathrm{P}=$ permanent ponds, $\mathrm{T}=$ temporary ponds.

influenced by the duration of desiccation events in salt marsh ponds in Spain. Our data on the proportions of Wiggins et al. (1980) groups report no appreciable differences between permanent and temporary ponds. Indeed, Wiggins et al. (1980) indicated the presence of all four groups both in temporary (autumnal) and permanent 


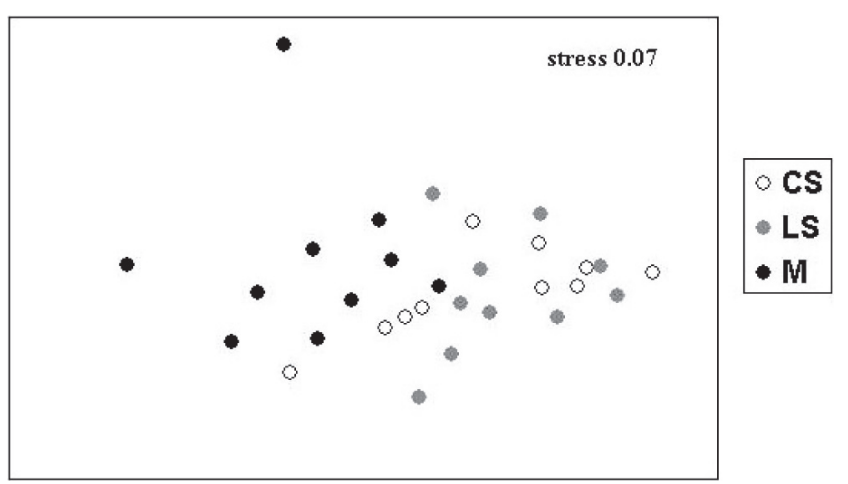

Fig. 5. Plot of Non-Metric Multidimensional Scaling (N-MDS) performed on the abundances of functional groups of 10 selected ponds in May 2002. CS = central sediments, LS = littoral sediments, $\mathrm{M}=$ macrophyte beds.

ponds, including those in which water fluctuates widely but never disappears, although group dominances were not recorded in their paper. Therefore, if the temporary or permanent character of ponds is important in controlling taxonomic distribution (Nicolet et al., 2004; Della Bella et al., 2005), we would expect that taxa showing adaptation to desiccation would be prevalent in temporary ponds, and especially in those of short duration. We only found a greater proportion of Group 4 in permanent ponds and only in March. Taxa belonging to this group, which display no form of resistance and have adult migrants, are known to be well represented in both biotope types, where they both feed on other invertebrates and avoid fish predation in temporary waters and colonized perennial waters when ponds dry up completely (Wiggins et al., 1980; Lake et al., 1989; Higgins and Merritt, 1999). They are generally considered opportunistic migrants or cyclic colonizers (Wissinger, 1997) and do not necessarily characterize a pond type. Our data show that the Wiggins et al. (1980) group composition was surprisingly similar in the two types of pond and especially in late spring when ponds are reduced in size. Both astatic pond types, those drying totally and those strongly reducing surface area without drying up, can, therefore, host macroinvertebrates with a comparable resistance to drought. This finding indicates that macroinvertebrate communities have a great potential ecological plasticity in astatic waters, which are generally subjected to widely varying drought periods throughout the year and from one year to the next. The wide reduction of water level, often observed in permanent ponds, seems, therefore, to act on some aspects of the fauna in a similar manner than a total drought typical of temporary ponds.

In the studied ponds wet phase duration therefore seemed to exert a strong influence in structuring species composition and the abundance of macroinvertebrates (Della Bella et al., 2005), while FFGs, habit and Wiggins groups appeared to be unaffected or only slightly affected by pond type. These observations extend those of Stein et al. (2003), who found that insect trophic guild composition in temporary ponds of different wet phase duration were similar, considering these environments to be more ecologically stable with respect to their unpredictable and ephemeral features. Even though the presence or abundance of some taxa clearly differed between our temporary and permanent ponds, the functional aspects point to baseline similarity because the same functional characteristics of the community are represented by different taxa in the two pond types.

\section{Differences among mesohabitats}

Unlike for the pond type analysis, there were marked differences among mesohabitats, with collector-gatherers, burrowers and animals belonging to Wiggins Group 1 which are more abundant in the sediments. Scrapers and shredders, sprawlers + climbers and swimmers + divers, and members Wiggins Group 4 predominated on the macrophyte beds. All these differences among mesohabitats can be explained by the higher habitat stability and heterogeneity of the macrophyte substrate compared with both littoral and central sediments (Schramm and Jirka, 1989; Harper et al., 1997). The vegetated substrate provides a more three-dimensional physical mesohabitat and shows a greater structural complexity, which reduces predation (Crowder and Cooper, 1982; Diehl and Kornijòw, 1998) and increases the available surface area especially for mobile taxa, such Ephemeroptera, Hemiptera and Coleoptera. These groups act as sprawlers, climbers, divers and swimmers belonging to Wiggins Group 4 and are recorded in higher abundances in this mesohabitat (see Della Bella et al., 2005). As already mentioned above, macrophytes also provide an abundant food sources such as senescent plants (CPOM) and periphyton for several organisms (Newman, 1991). This might justify the higher abundances of shredders (Hemiptera Corixidae, and partly of some Diptera Chironomidae) and scrapers (Gastropoda and Ephemeroptera) in the macrophyte stand. This substrate also creates favourable conditions for several macroinvertebrates (Carpenter et al., 1983; Schramm and Jirka, 1989) because it reduces the consequences of water movements, offering a more stable and well oxygenated habitat than sediments, subject to continuous drawdown (littoral) or water deoxygenation (central).

In our study, littoral sediments represent a suitable substrate for Diptera Ceratopogonidae, of which larvae and pupae (spawlers) reach the zone nearest to the air to metamorphose (Glukova, pers. comm.). On the other hand, sediments in the central zone of the ponds hosted higher abundances of burrowers and collector-feeders, such as Oligochaeta Tubificidae and partly Diptera Chironomidae, especially the subfamily Chironominae with Chironomus plumosus group and C. thummi group, which can live in deoxygenated, soft substrates and feed on FPOM (Merritt and Cummins, 1996). The absence of differences in functional aspects between these two sediment types is, however, quite unexpected because the littoral zone of ponds is exposed to continuous drying and 

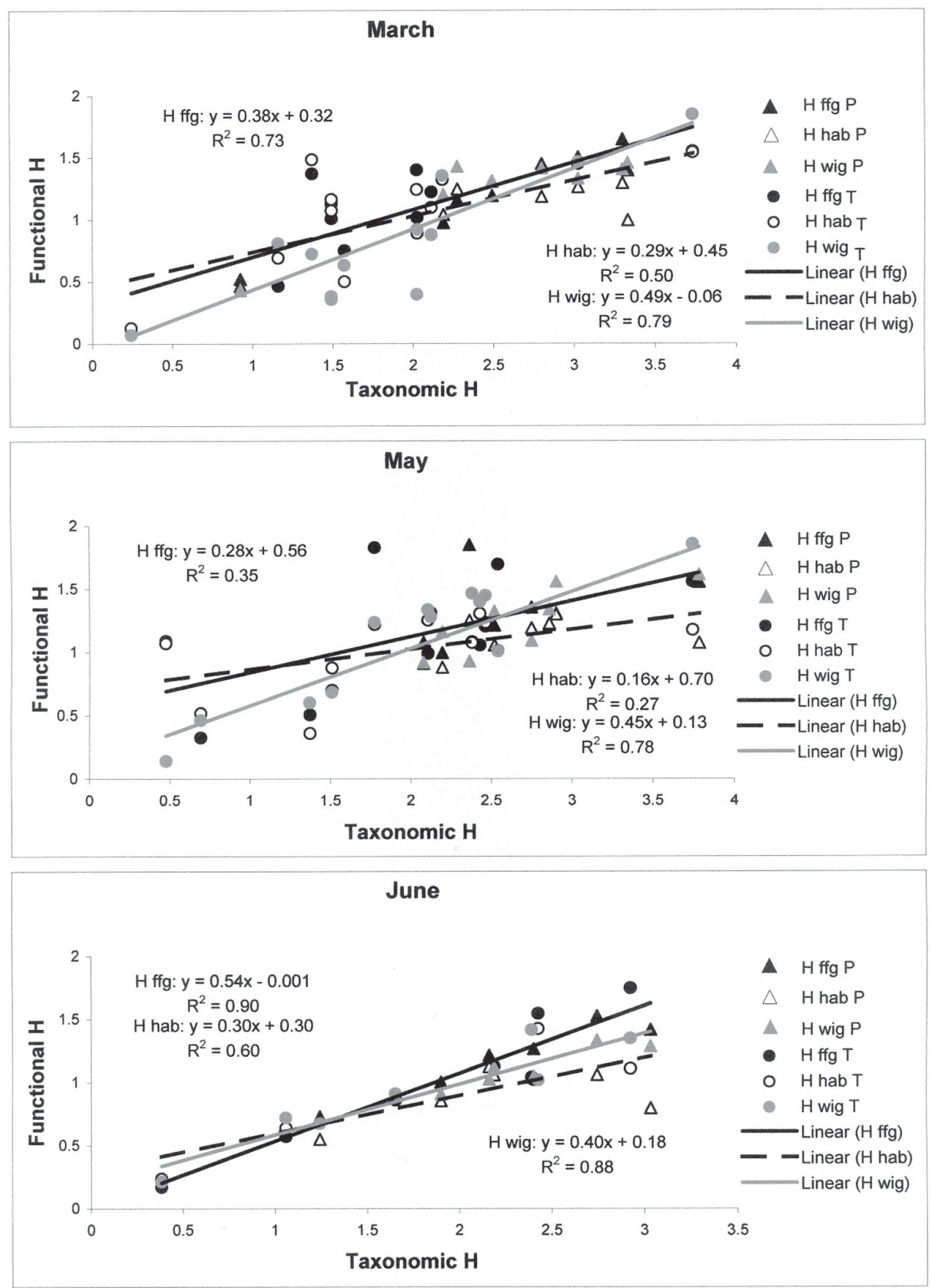

Fig. 6. Relationship between taxonomic diversity and three functional diversity metrics $\left(\mathrm{H}_{\mathrm{ffg}}, \mathrm{H}_{\text {hab }}\right.$ and $\left.\mathrm{H}_{\text {wig }}\right)$ of macroinvertebrate communities in temporary $(\mathrm{T})$ and permanent $(\mathrm{P})$ ponds for the three sampling months.

filling during the year depending on rainfall and temperature, and could be less suitable for invertebrate colonization than more stable central sediments. Our results indicate that the re-colonization of new flooded littorals occurs rapidly and involves the same functional groups as those found in the central zone of the ponds.

\section{Taxonomic vs. functional diversity}

The relationships between taxonomic and the three functional diversity metrics indicate that an increase in taxonomic diversity leads to a more equitable distribution of individuals among the categories of the three functional 
traits, which corresponds to a satisfactory partitioning of the ecological resources among taxa. In other words, high taxonomic diversity tends to maintain high FFG, habit and survival complexity in the ponds, and these relationships seem to be independent from pond types related to water permanence. Moreover, the higher values of all diversity types in the macrophytes than in the sediments support the claim by Brönmark (1985), Schramm and Jirka (1989) and Beckett et al. (1992) that macrophytes are a key factor in the maintenance of macroinvertebrate biodiversity in ponds and lakes.

For plant communities Díaz and Cabido (2001) claimed that ecosystem functioning is linked to both species diversity and functional diversity, and stressed that "Crossfertilization between these two approaches is a promising way of gaining mechanistic insight into the links between plant diversity and ecosystem processes and contributing to practical management for the conservation of diversity and ecosystem services". So, further studies on the relationships between these two community diversity types are still needed to explore the basic ecological functioning of ponds and to determine what practical steps can be taken for their protection.

\section{Concluding remarks}

Previous studies on macroinvertebrates in the same ponds suggest that hydroperiod is the driving force explaining their taxonomic composition and abundance (Della Bella et al., 2005), whereas the overall shape of their size spectrum is similar among pond types and among mesohabitats (Solimini et al., 2005). In the present study, hydroperiod seemed to be a less important factor governing community functional aspects, which on the contrary appeared greatly influenced by the substratum types. Therefore, matching species functional traits to mesohabitat characteristics can provide important insights into the functioning of pond communities. Macroinvertebrates are important contributors to ecosystem functions, including detritus processing, herbivory and energy transfer to consumers, occupying different spatial niches and showing a wide variety of drought survival modalities. This functional versatility is the result of a multitude of adaptations that benthic invertebrates have evolved in response to the complex nature of astatic water bodies. Data on factors affecting the functional organization of macroinvertebrate communities are therefore not only vital for a basic ecological understanding and biodiversity conservation (De Meester et al., 2005), but also as references for monitoring and maintaining water quality in ponds (Solimini et al., 2008).

Acknowledgements. The study was supported by a MURST $60 \%$ grant to M.B. and a Ph.D. studentship granted to V.D.B. by "Sapienza" University of Rome. We wish to thank two anonymous reviewers for their suggestions on the early version of the manuscript.

\section{References}

Barbour M.T., Gerritsen J., Snyder B.D. and Stribling J.B., 1999. Rapid bioassessment protocols for use in streams and wadeable rivers: periphyton, benthic macroinvertebrates and fish, EPA 841-B-99-002, U.S. Environmental Protection Agency, Office of Water, Washington, D.C.

Bataille K.J. and Baldassarre G.A., 1993. Distribution and abundance of aquatic macroinvertebrates following drought in three prairie pothole wetlands. Wetlands, 13, 260-269.

Batzer D.P., Palik B.J. and Buech R., 2004. Relationships between environmental characteristics and macroinvertebrate communities in seasonal woodland ponds of Minnesota. J. N. Am. Benthol. Soc., 23, 50-68.

Bazzanti M. and Della Bella V., 2004. Functional feeding and habit organization of macroinvertebrate communities in permanent and temporary ponds in Central Italy. $J$. Freshwat. Ecol., 19, 493-497.

Bazzanti M., Baldoni S. and Seminara M., 1996. Invertebrate macrofauna of a temporary ponds in Central Italy: composition, community parameters and temporal succession. Arch. Hydrobiol., 137, 77-94.

Bazzanti M., Seminara M., Baldoni S. and Stella A., 2000. Macroinvertebrates and environmental factors of some temporary and permanent ponds in Italy. Verh. Internat. Verein. Limnol., 27, 936-941.

Bazzanti M., Della Bella V. and Seminara M., 2003. Factors affecting macroinvertebrate communities in astatic ponds in central Italy. J. Freshwat. Ecol., 18, 537-548.

Bazzanti M., Grezzi F. and Della Bella V., 2008. Chironomids (Diptera) of temporary and permanent ponds in Central Italy: a neglected invertebrate group in pond ecology and conservation. J. Freshwat. Ecol., 23, 219-229.

Beckett D.C., Aartila T.P. and Miller A.C., 1992. Contrast in density of benthic invertebrates between macrophyte beds and open littoral patches in Eau Galle Lake, Wisconsin. Am. Midl. Nat., 127, 77-90.

Biggs J., Corfield A., Walker D., Whitfield M. and Williams P., 1994. New approaches to the management of ponds. British Wildlife, 5, 273-287.

Bremner J.M., 1965. Total nitrogen. In: Black C.A. (ed.), Method of soil analysis, American Society of Agronomy: Madison, WI, 1149-1178.

Brönmark C., 1985. Freshwater snail diversity: effects of pond area, habitat heterogeneity and isolation. Oecologia, 67, 127131.

Carpenter S.R., Elser J.J. and Olson K.M., 1983. Effects of roots of Myriophyllum verticillatum L. on sediment redox conditions. Aquat. Bot., 17, 243-249.

Clarke K.R. and Warwick R.M., 1994. Change in marine communities: an approach to statistical analysis and interpretation, Natural Environment Research Council, UK.

Collinson N.H., Biggs J., Corfield A., Hodson M.J., Walker D., Whitfield M. and Williams P.J., 1995. Temporary and permanent ponds: an assessment of the effects of drying out on the conservation value of aquatic macroinvertebrate communities. Biol. Conserv., 74, 125-133.

Crowder L.D. and Cooper W.E., 1982. Habitat structural complexity and the interaction between bluegills and their prey. Ecology, 63, 1802-1813. 
Culioli J.L., Foata J., Mori C., Orsini A. and Marchand B., 2006. Temporal succession of the macroinvertebrate fauna in a Corsican temporary pond. Vie Milieu, 56, 215-221.

Cummins K.W., 1962. An evaluation of some technique for the collection and analysis of benthic sample with special emphasis on lotic water. Am. Midl. Nat., 67, 447-504.

Cummins K.W. and Wilzbach M.A., 1985. Field procedures for analysis of functional feeding groups of stream invertebrates, Appalachian Environmental Laboratory, Maryland, Frostburg, Contr. n ${ }^{\circ} 1611$.

De Meester L., Declerck S., Stoks R., Louette G., van De Meutter F., De Bie T., Michels E. and Brendonck L., 2005. Ponds and pools as model systems in conservation biology, ecology and evolutionary biology. Aquat. Conserv. Mar. Freshwat. Ecosyst., 15, 715-725.

Della Bella V., Bazzanti M. and Chiarotti F., 2005. Macroinvertebrate diversity and conservation status of Mediterranean ponds in Italy: water permanence and mesohabitat influence. Aquat. Conserv. Mar. Freshwat. Ecosyst., 15, 583-600.

Della Bella V., Bazzanti M. and Grezzi F., 2006. Il ruolo della Riserva Presidenziale di Castelporziano nella conservazione dei macroinvertebrati delle piccole raccolte d'acqua lentiche del litorale tirrenico nei pressi di Roma. In: Accademia Nazionale delle Scienze detta Dei Quaranta (ed.), Il sistema ambientale della Tenuta Presidenziale di Castelporziano, Ricerche sulla complessità di un ecosistema forestale costiero mediterraneo, Seconda serie. "Scritti e documenti", XXXVII, 703-723.

Della Bella V., Puccinelli C., Marcheggiani S. and Mancini L., 2007. Benthic diatom communities and their relationship to water chemistry in wetlands of Central Italy. Ann. Limnol. Int. J. Lim., 43, 89-99.

Della Bella V., Bazzanti M., Dowgiallo M.G. and Iberite M., 2008. Macrophyte diversity and physico-chemical characteristics of Tyrrhenian coast ponds in central Italy: implications for conservation. Hydrobiologia, 597, 85-95.

Díaz S. and Cabido M., 2001. Viva la difference: plant functional diversity matters to ecosystem process. Trends Ecol. Evol., 16, 646-55.

Diehl S. and Kornijòw R., 1998. Influence of submerged macrophytes on trophic interaction among fish and macroinvertebrates. In: Jeppesen E., Søndergaard Ma., Søndergaard Mo. and Christoffersen K. (eds.), The structuring role of submerged macrophytes in lakes, Springer, New York, 24-46.

Dvořak J., 1996. An example of relationships between macrophytes, macroinvertebrates and their food resources in a shallow eutrophic lake. Hydrobiologia, 339, 27-36.

Dvořak J. and Best E.P.H., 1982. Macro-invertebrate communities associated with the macrophytes of Lake Vechten: structural and functional relationships. Hydrobiologia, 95, 115-126.

E.P.C.N., 2007. Developing the Pond Manifesto. Ann. Limnol. Int. J. Lim., 43, 221-232.

Gascon S., Boix D., Sala J. and Quintana X.D., 2008. Relation between macroinvertebrate life trategies and habitat traits in Mediterranean salt marsh ponds (Emporda' wetlands, NE Iberian Peninsula). Hydrobiologia, 597, 71-83.

Gaudette H.E., Flight W.R., Toner L. and Folger D.W., 1974. An inexpensive titration method of the determination of organic carbon in recent sediments. J. Sedim. Petrol., 44, 249-253.
Harper D., Mekotova J., Hulme S., White J. and Hall J., 1997. Habitat heterogeneity and aquatic invertebrate diversity in floodplain forests. Global Ecol. Biogeogr. Lett., 6, 275-285.

Heino J., 2000. Lentic macroinvertebrate assemblage structure along gradients in spatial heterogeneity, habitat size and water chemistry. Hydrobiologia, 418, 229-242.

Heino J., 2005. Functional biodiversity of macroinvertebrate assemblages along major ecological gradients of boreal headwater streams. Freshwat. Biol., 50, 1578-1587.

Higgins M.J. and Merritt R.W., 1999. Temporary woodland ponds in Michigan. Invertebrate seasonal patterns and trophic relationships. In: Batzer D.P., Rader R.B. and Wissinger S.A. (eds.), Invertebrates in freshwater wetlands of North America: ecology and management, John Wiley \& Sons, Inc., 279-297.

IRSA-CNR, 1994. Metodi analitici per le acque, Istituto Poligrafico e Zecca dello Stato.

Kerans B.L. and Karr J.R., 1994. A benthic index of biotic integrity (B-IBI) for rivers of the Tennessee Valley. Ecol. Appl., 4, 768-785.

Lake P.S., Bayly I.A.E. and Morton D.W., 1989. The phenology of a temporary pond in Western Victoria Australia, with special reference to invertebrate succession. Arch. Hydrobiol., $115,171-202$.

Marengo G. and Baudo R., 1988. Forme del fosforo nei sedimenti lacustri. Acqua Aria, 6, 717-721.

Merritt R.W. and Cummins K.W., 1996. An introduction to the aquatic insects of North America, Kendall/Hunt, Dubuque.

Newman R.M., 1991. Herbivory and detritivory on freshwater macrophytes by invertebrates: a review. J. N. Am. Benthol. Soc., 10, 89-114.

Nicolet P., Biggs J., Fox G., Hodson M.J., Reynolds C., Withfield M. and Williams P., 2004. The wetland plant and macroinvertebrate assemblages of temporary ponds in England and Wales. Biol. Conserv., 120, 265-282.

Nicolet P., Ruggiero A. and Biggs J., 2007. Second European Pond Workshop: Conservation of pond biodiversity in a changing European landscape. Ann. Limnol. - Int. J. Lim., 43, 77-80.

Oertli B., Joye D.A., Castella E., Juge R., Cambin D. and Lachavanne J.B., 2002. Does size matter? The relationship between pond area and biodiversity. Biol. Conserv., 104, 59-70.

Pardo I. and Armitage P.D., 1997. Species assemblages as descriptors of mesohabitats. Hydrobiologia, 344, 111-128.

Pielou E.C., 1969. An Introduction to Mathematical Ecology, Wiley, New York.

Rees S.E., 1997. The historical and cultural importance of ponds and small lakes in Wales, UK. Aquat. Conserv. Mar. Freshwat. Ecosyst., 7, 133-139.

Regione Lazio, 2004. La rete natura 2000 nel Lazio. Caratterizzazione dei siti di importanza comunitaria e delle zone di protezione dell'attuazione della sottomisura. I.1.2, 2nd edn., Assessorato Ambiente, Dipartimento Territorio, Direzione Generale Ambiente e Protezione Civile: Roma.

Ross R.M., Lellis W.A., Bennett R.M. and Johnson C.S., 2001. Landscape determinants of nonindigenous fish invasions. Biol. Invasions, 3, 347-361.

Schneider D.W. and Frost T.M., 1996. Habitat duration and community structure in temporary ponds. J. N. Am. Benthol. Soc., 15, 64-86. 
Schramm H.L. Jr and Jirka K.J., 1989. Effects of aquatic macrophytes on benthic macroinvertebrates in two Florida lakes. J. Freshwat. Ecol., 5, 1-12.

Solimini A.G., Della Bella V. and Bazzanti M., 2005. Macroinvertebrate size spectra of Mediterranean ponds with differing hydroperiod length. Aquat. Conserv. Mar. Freshwat. Ecosyst., 15, 601-611.

Solimini A.G., Bazzanti M., Ruggiero A. and Carchini G., 2008. Developing a multimetric index of ecological integrity based on macroinvertebrates of mountain ponds in central Italy. Hydrobiologia, 597, 109-123.

Sokal R.R. and Rohlf G., 1973. Introduction to biostatistic, Freeman \& Co.

Stein K.J., Mitchell J.C., Smith E.P. and Waldon J.L., 2003. Trophic level distribution of ephemeral pool insects: uniformity among pools. J. Freshwat. Ecol., 18, 549-556.

Studinski J.M. and Grubbs S.A., 2007. Environmental factors affecting the distribution of aquatic invertebrates in temporary ponds in Mammoth Cave National Park, Kentucky, USA. Hydrobiologia, 575, 211-220.

Tockner D., Armitage P.D., Bickerton M.A. and Hall K.A., 2000. Assessing stream quality using information on mesohabitat distribution and character. Aquat. Conserv. Mar. Freshwat. Ecosyst., 10, 179-196.

Tolonen K.T., Hämäläinen H., Holopainin L.J. and Karjalainin J., 2001. Influences of habitat type and environmental variables on littoral macroinvertebrate communities in a large lake system. Arch. Hydrobiol., 152, 39-67.

Usseglio-Polatera P., Richoux P., Bournaud M. and Tachet H., 2001. A functional classification of benthic macroinvertebrates based on biological and ecological traits: application to river condition assessment and stream management. Arch. Hydrobiol., 139, Suppl., 53-83.

Vannote R.L., Minshall G.W., Cummins K.W., Sedell J.R. and Cushing C.E., 1980. The River Continuum Concept. Can. J. Fish. Aquat. Sci., 37, 130-137.

Wetzel R.G. and Likens G.E., 2000. Limnological analyses, 3rd edn., Springer-Verlag, New York.

White J. and Irvine K., 2003. The use of littoral mesohabitats and their macroinvertebrate assemblages in the ecological assessment of lakes. Aquat. Conserv. Mar. Freshwat. Ecosyst., 13, 331-351.

Wiggins G.B., Mckay R.J. and Smith I.M., 1980. Evolutionary and ecological strategies of animals in annual temporary pools. Arch. Hydrobiol., 58, Suppl., 97-206.

Williams W.D., 1985. Biotic adaptation in temporary lentic waters, with special reference to those in semi-arid and arid regions. Hydrobiologia, 125, 85-110.

Williams D.D., 1987. The ecology of temporary waters, Croom Helm, London \& Sydney, Timber Press, Portland.

Wissinger S.A., 1997. Cyclic colonization in predictably ephemeral habitats: a template for biological control in annual crop systems. Biol. Contr., 10, 4-15. 